Brit. J. vener. Dis. (1960), 36, 261.

\title{
TABETIC SPINAL ARTHROPATHY* TWO CASES WITH MOTOR SYMPTOMS DUE TO ROOT COMPRESSION
}

\author{
BY \\ C. D. ALERGANT \\ Newsham General Hospital, Liverpool
}

The characteristic arthropathy which may complicate tabes dorsalis was first described by Charcot (1868). The earliest reference to tabetic spinal arthropathy, however, would appear to be that of Krönig (1884) who recorded an example as "A case of Spondylolisthesis in a Tahetic". Abadie (1900) described fourteen cases, with illustrations of the affected vertebrae as they appeared post mortem.

More recent descriptions have been given by Holland (1953), who described five cases illustrated by radiographs, and by Campbell and Doyle (1954), who described eight cases and concluded that the condition was more common than is generally accepted and suggested that the spine should be $x$-rayed in all cases with severe and persistent root pains:

"Considerable discomfort is often caused by pressure of the collapsing spine and that of hypertrophic bone formation upon the spinal nerves. These root pains are usually gradual and insidious in onset and of moderate severity. Occasionally, however, they attain considerable intensity, somewhat simulating gastric crises or peptic ulcer pains. The mobility of the spine is little involved except in cases of excessive destruction."

Although these authors rightly stressed the importance of Charcot spine as a cause of root pains resulting from pressure on posterior nerve roots, consideration was not given to the possibility of symptoms arising as a result of pressure on anterior nerve roots. As this complication would appear not to have been described previously two cases are here reported of tabetic spinal arthropathy complicated by severe lower motor neurone paralysis resulting from pressure on anterior spinal roots.

Case 1, a white male born in 1902, was first seen in 1951, when he was admitted to hospital for investigation of umbilical pain during the previous 18 months. Barium enema examination revealed a diverticulitis affecting the sigmoid colon. Clinical examination, however, had revealed pupils which were fixed to light and irregular in size. The blood Wassermann reaction was strongly positive and cerebro-spinal fluid examination showed:

\footnotetext{
* Received for publication December 91959.
}

cells, $71 / \mathrm{cmm}$.; protein, $110 \mathrm{mg}$. per cent.; globulin, increased; Lange, 0001210000; Wassermann reaction, positive in all dilutions.

In addition to the pupillary changes, hypoalgesia was present over the pre-tibial area and the soles of the feet, and there was absence of pain on pinching the Achilles tendon. Light touch was normal and vibration sense was unimpaired. Knee and ankle jerks were present. There was no history of lightning pains. He was given a course of 15 mega units P.A.M. together with dietary treatment for his diverticulitis, and after his discharge from hospital returned to work free of symptoms.

During the years 1951 to 1957 this patient continued to attend as an out-patient. Between 1952 and 1954 he was given five further courses of P.A.M. to a total of $91 \cdot 2$ mega units. In April, 1953, he complained of lightning pains in the left foot and calf, but these apparently were not severe and during the whole of this time he continued to work, first as a sheet-metal worker and later as a storekeeper, and to indulge regularly in his hobby of ballroom dancing. In June, 1953, the cerebrospinal fluid was re-examined with the following result: cells, $3 / \mathrm{cmm}$.; protein, $40 \mathrm{mg}$. per cent.; globulin, very slight increase; Lange, 4333221000; Wassermann reaction positive $\mathbf{0} \cdot 5, \mathbf{0} \cdot 25,0.1 \mathrm{ml}$., and negative $0.05 \mathrm{ml}$.

The blood Wassermann reaction became negative in July, 1954, and has since fluctuated between negative and weakly positive.

At the beginning of January, 1958, the patient suddenly developed a right foot-drop for which a drop-foot spring was prescribed. In April, weakness developed in the left foot. Lightning pains in both legs and feet were now very severe and he was re-admitted to hospital for further investigation.

Examination showed moderate weakness of dorsiflexion of the left foot and almost complete loss of dorsiflexion of the right foot. The knee and ankle jerks previously present were now lost. There was no increased sensory loss, but the heel to knee test on the left side was slightly affected. During the first week in hospital he became grossly ataxic and unaided walking became almost impossible.

The results of laboratory investigations were as follows:

Wassermann Reaction: Negative.

Cerebrospinal Fluid: Cells, 13/cmm. (lymphocytes 70 per cent., polymorphs 30 per cent.); protein, $200 \mathrm{mg}$. 
per cent.; globulin, increased; Lange, $0^{10}$; Wassermann reaction, positive $0.5 \mathrm{ml}$, and negative $0 \cdot 25,0 \cdot 1$, and $0.05 \mathrm{ml}$.

\section{Radiology of Lumbo-sacral Spine:}

"There are destructive bone changes involving the anterior aspects of the bodies of $\mathrm{L} 4$ and 5 adjacent to the intervertebral disk, which is itself practically obliterated. The disk space L5/S1 is also narrowed. Dense bone sclerosis is also shown throughout the bodies of L4 and 5 and also the first piece of the sacrum. The appearances are consistent with specific osteitis" (Figs 1 and 2).

During the 6 months which this patient remained in hospital, walking improved until he was able to get about quite well with two sticks, toe-springs having previously been fitted to both feet and a year later this progress had been maintained. The bilateral foot-drop, however, showed no signs of recovery and there was reduced power in the whole of the lower limbs. Wasting was marked, the glutei and the anterior tibial group of muscles being particularly affected. Whilst the patient was in hospital the radiological picture remained unchanged, but later radiographs (November, 1959) showed some further progression.
Between June, 1958, and February, 1959, the patient was treated with a further 51.6 mega units P.A.M. The most recent cerebrospinal fluid examination in April 1959 , showed a reduction of the cell count to less than $1 / \mathrm{cmm}$., but the protein was still $150 \mathrm{mg}$, per cent. and the globulin increased.

Case 2, a white male born in 1910, was found to be suffering from tabes dorsalis in 1948, when he was investigated for various paraesthesiae and shooting pains. Clinical examination showed pupils fixed to light, absent knee and ankle jerks, and impaired response to pin prick and light touch over the nose, certain areas of the trunk, the thighs, and the front of legs. The gait was normal and there was no Rombergism. The blood Wassermann reaction was negative. The cerebrospinal fluid showed: cells, $25 / \mathrm{cmm}$.; protein, $60 \mathrm{mg}$. per cent.; globulin, slight increase; Lange, 4443321000 ; Wassermann reaction, positive in all dilutions.

18 months later in February, 1950, after two courses of P.A.M. totalling 14 mega units, the cerebrospinal fluid became completely normal. During the next 6 years the patient continued to attend regularly as an out-patient

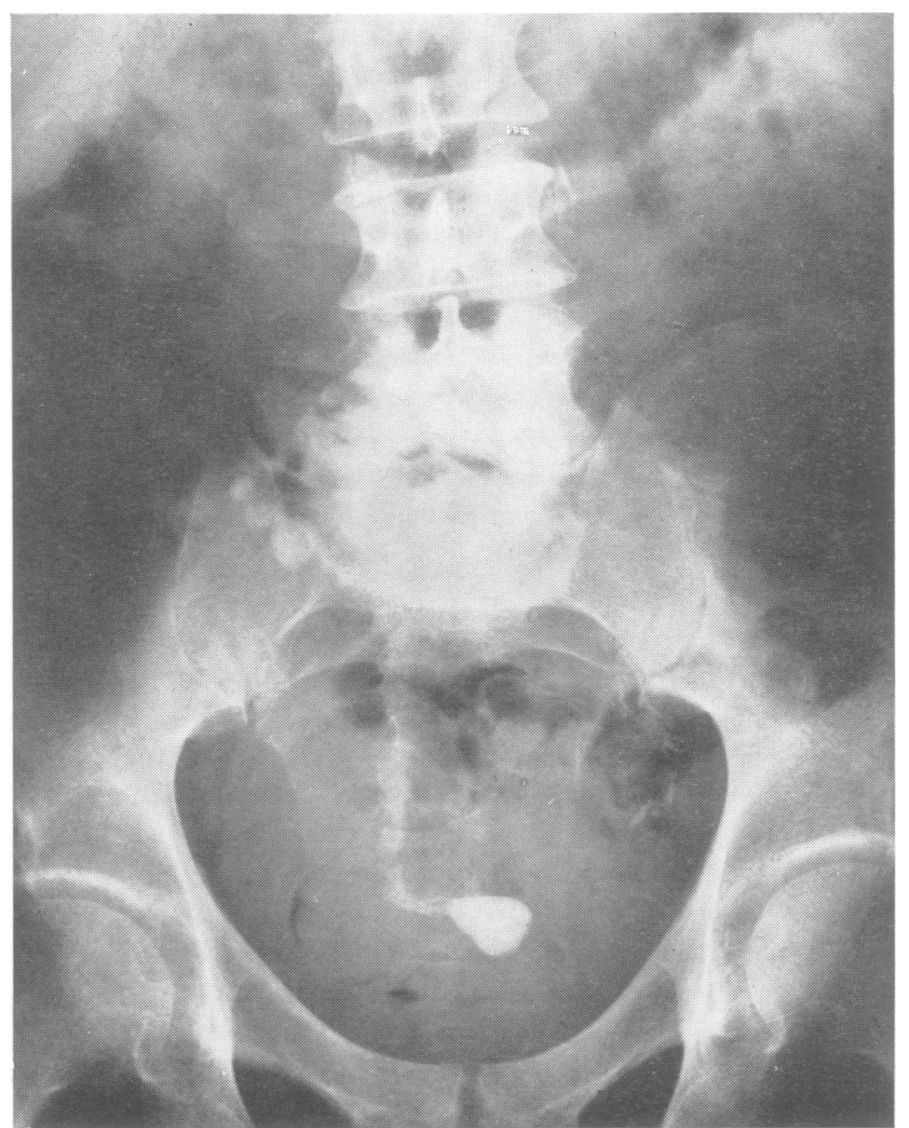

Fig. 1.-Case 1, July, 1958. 


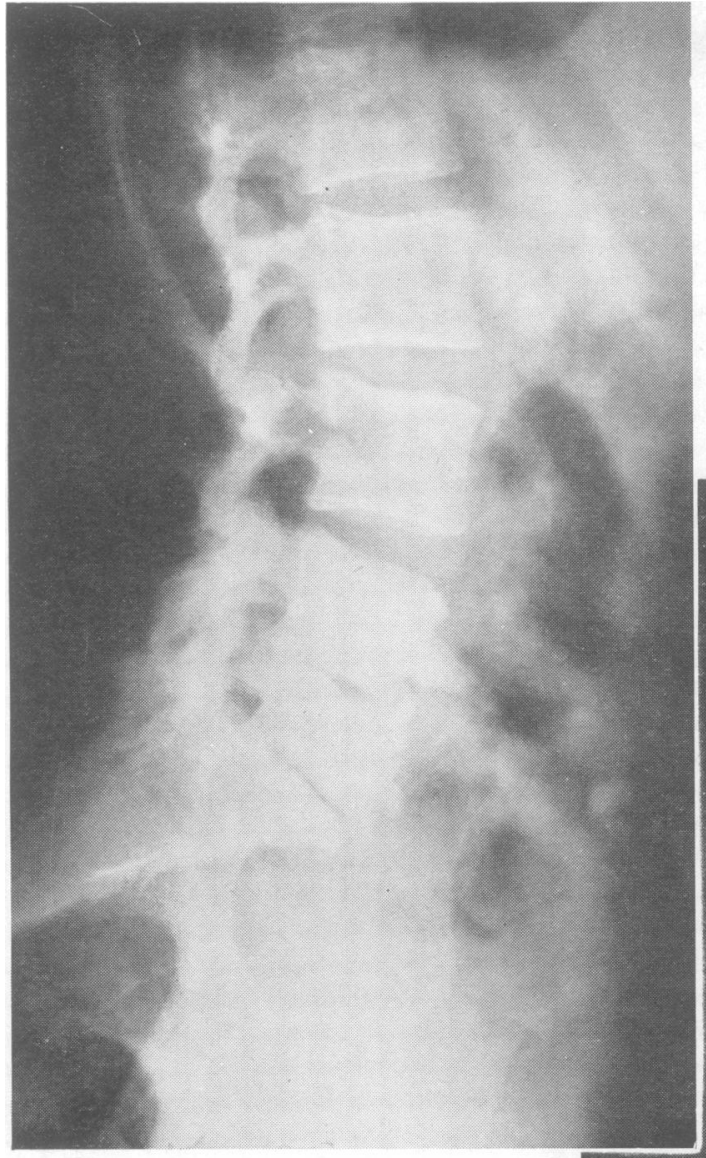

and received further P.A.M. (52.8 mega units). Despite frequent troublesome lightning pains and the added disability of osteo-arthritis affecting both knees, he continued to work as a motor driver.

In February, 1956, in an endeavour to discover a case of Charcot spine to demonstrate at a clinical meeting, the lumbo-sacral region was x-rayed in a number of patients with tabes. The radiologist reported on this patient as follows (Fig. 3):

"There are hypertrophic bone changes in the lower lumbar spine with sclerosis of the bodies of the vertebrae and loss of disk-spacing between L3 and 4, L4 and 5, and L5 and S1. The appearances would be consistent with a Charcot's disease of the spine.'

Fig. 2.-Case 1, July, 1958.

FIG. 3.-Case 2, Feb., 1956.

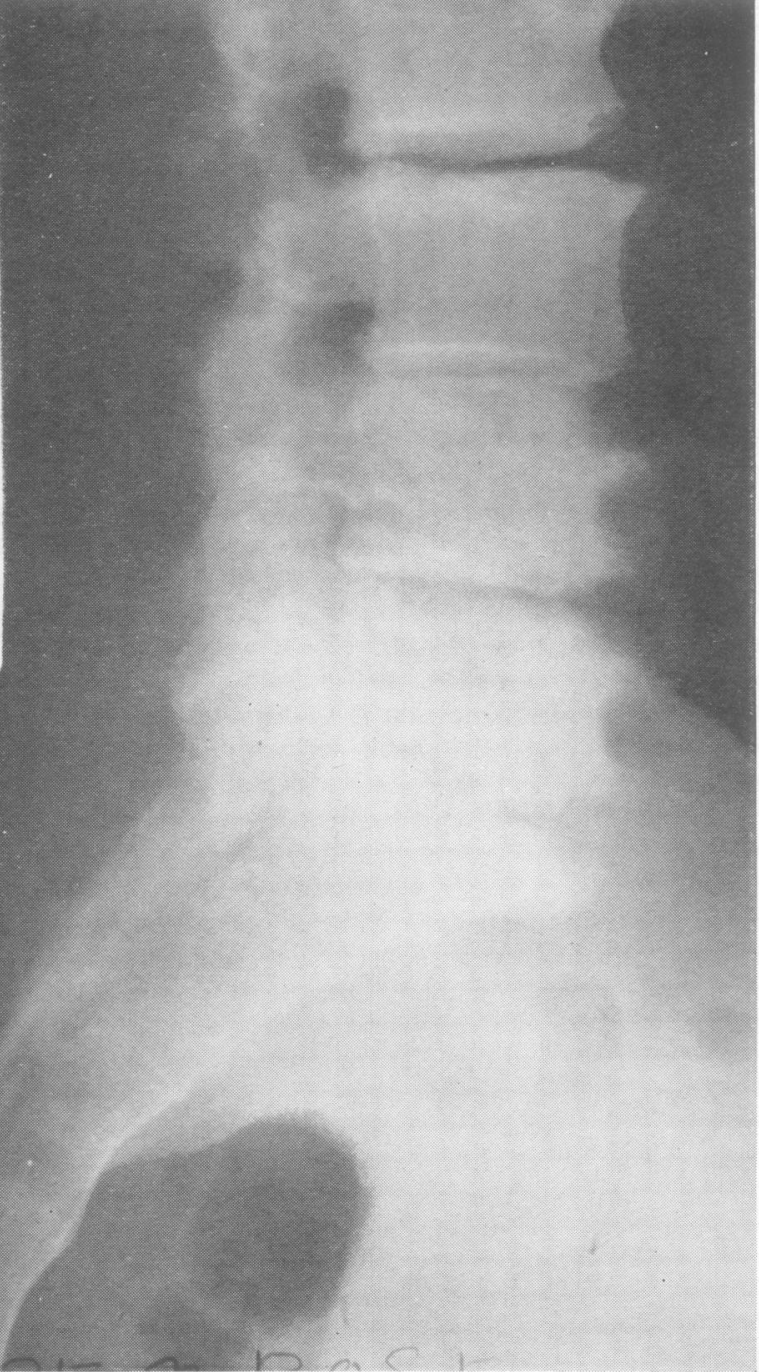


In August, 1958, because of a marked exacerbation of lightning pains in both calves during the previous 3 months, he was re-admitted to hospital. In September, 1958 , it was noticed that he was unable to dorsiflex the right big toe. A fortnight later dorsiflexion of the whole foot was affected, and in November the left foot became similarly affected. Two attempts at lumbar puncture were unsuccessful. Radiographs showed changes which were similar to but more extensive than those reported in 1956. Toe-springs were fitted to both feet and the patient was able to walk moderately well on discharge from hospital in January, 1959.

During the next 6 months he continued to attend as an out-patient. In April, 1959, an attempt at lumbar puncture was more successful, although the specimen of cerebrospinal fluid obtained was slightly contaminated with blood: lymphocytes, $5 / \mathrm{cmm}$.; protein, $80 \mathrm{mg}$. per cent.; globulin, not increased; Wassermann reaction, negative in all dilutions.

In July, 1959, increasing weakness of the legs had forced the patient to give up work; his walking had clearly deteriorated and he was once more admitted to hospital. He was now barely able to stand, being just able to support himself with the hips flexed. In addition to the weakness of the hip muscles both quadriceps were markedly wasted. There was complete foot-drop on the right side, and on the left there was loss of dorsiflexion and of eversion at the ankle joint. Wasting was most marked in the thigh muscles. The spine is shown in Fig. 4. In November, 1959, there was little change in his condition. A surgical corset was fitted, and he walked with difficulty using two sticks.

\section{Discussion}

The development of Charcot joints in conditions other than tabes dorsalis and their experimental production in cats (Eloesser, 1917) after spinal root section make it clear that the Treponema pallidum is not directly concerned in their aetiology. It is now generally agreed that neuropathic joints result from the effects of repeated trauma in joints which have lost their protective pain sense. It should, therefore, occasion no surprise that Charcot joints should develop in two patients both of whom had previously been treated with very considerable amounts of penicillin and whose spinal fluids would, by generally accepted criteria, be considered inactive. The increased cell count and the raised protein content of the spinal fluid cannot be adduced as evidence of renewed activity of a neurosyphilitic process; similar changes may result from any form of meningeal irritation and an increase of protein commonly occurs in cases of prolapsed intervertebral disk (Brain, 1947). Moreover, further treatment with penicillin did not restore the protein to normal levels. On the other hand, it is worth recording and possibly of some significance that the first patient was found to have developed an aortic diastolic

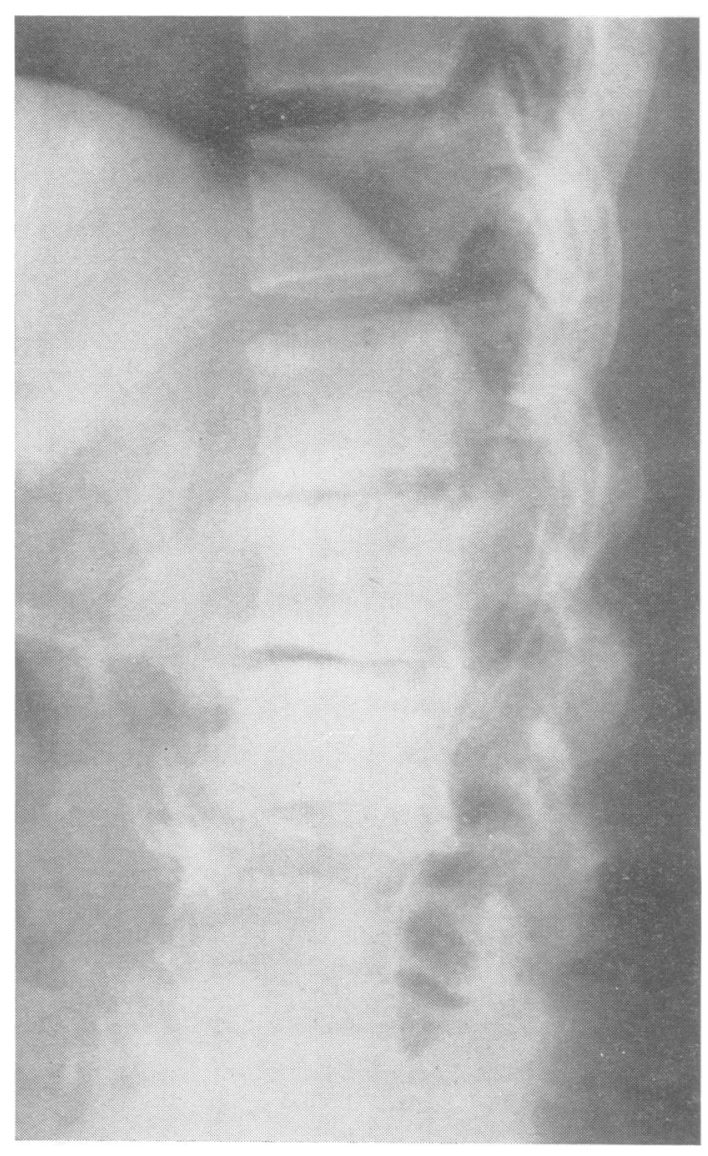

FIG. 4.-Case 2, Oct., 1959.

murmur B.P. $170 / 75$ in 1958 , whereas no such murmur had been detected in 1951 .

When one examines the radiographs (Figs 1, 2, $3,4)$ and observes the gross deformities which have developed in the lumbo-sacral spine, it occasions no surprise that the motor nerve roots should have sustained damage. It is, however, surprising that this particular complication appears so far to have escaped recognition.

Penicillin therapy has prolonged the working life of many tabetics who would previously have gradually developed progressively incapacitating ataxia or have died from intercurrent infection. Bedridden patients, one can assume, are far less liable to develop Charcot spines. Moreover, in the institutions for the chronic sick where previously many of these patients were nursed, it is more than likely that such complications would fail to be recognized. 
The spine is still regarded as the least common site for the development of Charcot joints in tabetics: more frequent radiological examination of the lumbo-sacral spine would almost certainly cause such views to be modified and might bring to light further examples of anterior root damage. If a Charcot spine is discovered on routine $x$-ray examination, orthopaedic advice should be obtained at the earliest opportunity in an endeavour to forestall the development of incapacitating symptoms. The recognition of this latest danger to which tabetics are liable further emphasizes the importance of keeping these patients under observation indefinitely, irrespective of the serological findings or of the amount of treatment that may have been administered.

\section{Summary}

The history and symptomatology of tabetic spinal arthropathy are briefly reviewed. Although previous descriptions have stressed that symptoms may occur as a result of pressure on posterior nerve roots, the occurrence of symptoms resulting from pressure on anterior nerve roots appears not to have been previously described.

Two patients suffering from tabes dorsalis are reported, who had been treated with considerable amounts of P.A.M. Subsequently, after a lapse of several years during which time there were no signs of clinical activity, both patients developed foot drop which was followed by marked weakness of the whole of the lower limbs. In both cases $x$ rays showed very marked destructive changes affecting the lumbo-sacral vertebrae of a type characteristic of tabetic arthropathy.

It is suggested that because penicillin therapy has prolonged the working lives of many tabetics, Charcot spines occur more frequently than hitherto and that further cases of anterior root damage due to this cause will be recognized in the future. The importance is stressed of keeping tabetics under observation indefinitely, irrespective of serological findings or of the amount of treatment administered.

\section{REFERENCES}

Abadie, J. (1900). Nouv. Iconogr. Salpêtrière, 13, 116, 260, 425, 502. Brain, R. (1947). "Diseases of the Nervous System", 3rd ed., p. 770. Oxford University Press, London.

Campbell, D. J., and Doyle, J. O. (1954). Brit. med. J., 1, 1018. Charcot, J. M. (1868). Arch. Physiol. norm. path., 1., 161, 379. Eloesser, L. (1917). Ann. Surg., 66, 201.

Holland, H. W. (1953). Proc. roy. Soc. Med., 46, 747.

Krönig, G. (1884). Z. klin. Med., 7, "Festschrift F. T. von Frerichs". Suppl., p. 165.

\section{Résumé}

On passe rapidement en revue l'histoire et la symptomatologie de l'arthropathie vertébrale tabétique. Bien que des descriptions antérieures aient insisté sur le fait que les symptômes peuvent résulter d'une pression sur les racines nerveuses postérieures, il apparaît que l'on n'a pas mentionné la survenance de symptômes à la suite d'une pression sur les racines nerveuses antérieures.

On signale deux malades souffrant de tabes dorsal qui avaient été traités avec des quantités considérables de P.A.M. (pénicilline-procaīne avec monostéarate d'aluminium). Par la suite, après plusieurs années pendant lesquelles il n'y eut aucun signe d'évolution morbide, les deux malades subirent un fléchissement du pied, suivi d'une faiblesse prononcée des deux jambes. Dans chaque cas les radiographies montrèrent des altérations destructives prononcées affectant les vertèbres lombo-sacrés caractéristiques d'arthropathie tabétique.

On suppose que, le traitement par la pénicilline ayant prolongé la vie active de nombreux tabétiques, l'épine de Charcot se voit plus souvent qu'auparavant, et que des cas ultérieurs de lésion des racines antérieures due à cette cause seront reconnus à l'avenir. On insiste sur l'importance de suivre les tabétiques indéfiniment, sans tenir compte des verdicts sérologiques ou du traitement. 